Indonesian Journal of Legality of Law
e-ISSN : 2477-197X
https://postgraduate.universitasbosowa.ac.id/

\title{
ANALISIS TANGGUNG JAWAB PENYIDIK KEPOLISIAN TERHADAP TERSANGKA YANG MELARIKAN DIRI DAN MASIH DALAM TAHAP PENAHANAN PENYIDIK PADA KEPOLISIAN DAERAH SULAWESI BARAT
}

\section{Responsibility Analysis Of Police Investigators On Suspects Who Escape And Still In The Stage Of Investigators' Detention At The West Sulawesi Regional Police}

\author{
Muh. Ikrar AR. ${ }^{1}$, Marwan Mas ${ }^{2}$, Abd. Haris Hamid ${ }^{2}$ \\ ${ }^{1}$ Kepolisian Daerah Provinsi Sulawesi Barat \\ ${ }^{2}$ Program Studi Ilmu Hukum Program Pascasarjana Universitas Bosowa \\ Email: muh.ikrar.ar121@gmail.com \\ Diterima: 10 September 2021/Disetujui: 21 Desember 2021
}

\begin{abstract}
ABSTRAK
Penelitian ini bertujuan Untuk mengetahui dan menganalisis tanggung jawab penyidik terhadap tersangka yang melarikan diri dan masih dalam tahap penahanan penyidik pada Kepolisian Daerah Sulawesi Barat dan Untuk mengetahui dan menganalisis bentuk sanksi yang dijatuhkan kepada penyidik terhadap tersangka yang melarikan diri dan masih dalam tahap penahanan penyidik pada Kepolisian Daerah Sulawesi Barat .Jenis penelitian yang digunakan adalah jenis penelitian Yuridis Empirik, yaitu penelitian hukum mengenai pemberlakuan atau implementasi ketentuan hukum normatif secara in action pada setiap peristiwa hukum tertentu yang terjadi dalam masyarakat, metode pendekatan yuridis empirik digunakan untuk mengkaji atau menganalisis data primer yang berupa data - data di lapangan tempat penelitian, hasil wawancara langsung yang diajukan ke responden kemudian dihubungkan dengan data - data sekunder berupa bahan - bahan hukum, untuk menganalisis tanggung jawab Penyidik Kepolisian Terhadap Tersangka Yang Melarikan Diri Dan Masih Dalam Tahap Penahanan Penyidik Pada Kepolisian Daerah Sulawesi Barat.
\end{abstract}

Kata Kunci: Analisis Tanggung Jawab, Penyidik, Tersangka Yang Melarikan Diri.

\begin{abstract}
This study aims to identify and analyze the responsibilities of investigators for suspects who fled and are still in the detention stage of investigators at the West Sulawesi Regional Police and to find out and analyze the form of sanctions imposed on investigators of suspects who fled and are still in the detention stage of investigators at the West Sulawesi Regional Police. The type of research used is empirical, juridical research, which is legal research regarding the enforcement or implementation of normative legal provisions in action on every particular legal event that occurs in society. The empirical juridical approach method is used to examine or analyze primary data in the form of field data from the location where the research is conducted. The results of direct interviews submitted to the respondents are then linked to secondary data in the form of legal materials, to analyze the responsibility of the Police Investigator for the suspect who escaped and is still in the Investigator's detention stage at the West Sulawesi Regional Police.
\end{abstract}

Keywords: Responsibility Analisis, Investigator, Runaway Suspect

(c) (1) This work is licensed under Creative Commons Attribution License 4.0 CC-BY International license

\section{PENDAHULUAN}

Undang - Undang Dasar Negara Republik Indonesia tahun 1945 pada Pasal 30 ayat (4) disebutkan bahwa Kepolisian Negara Republik Indonesia sebagai alat negara yang menjaga keamanan dan ketertiban masyarakat yang bertugas untuk melindungi, mengayomi, melayani masyarakat, serta menegakkan hukum. Pasal tersebut menerangkan tentang Kepolisian Negara Republik Indonesia yang memiliki tugas melindungi, mengayomi, melayani masyarakat, dan menegakkan hukum di negara kita ini supaya terciptanya suatu kenyamanan dan ketertiban di dalam masyarakat. Setelah Undang - Undang Nomor 8 Tahun 1981 tentang Kitab Undang - Undang Hukum Acara Pidana (KUHAP) diundangkan, perhatian terhadap hak asasi manusia di Indonesia dijunjung tinggi, sebab seseorang yang dianggap sudah melanggar hukum tidak lagi diperlakukan sebagai obyek semata melainkan harkatnya sebagai manusia (subyek) sangat diperhatikan sehingga proses beracara yang menangani pelanggar hukum dirasakan lebih manusiawi, sesuai dengan asas dalam hukum yaitu semua manusia tanpa terkecuali diperlakukan sama di mata hukum (Equality Before The Law). 
Dalam pelaksanaan tugas penjagaan tahanan secara khusus sudah diatur dalam Peraturan Pemerintah nomor 58 tahun 1999 tentang Syarat-Syarat dan Tata Cara Pelaksanaan Wewenang, Tugas, dan Tanggung Jawab Perawatan Tahanan, Peraturan Kapolri nomor 4 tahun 2005 tentang Pengurusan Tahanan pada Rumah Tahanan Kepolisian Negara Republik Indonesia, serta diatur pula dalam Peraturan Kepala Kepolisian Negara Republik Indonesia Nomor 6 Tahun 2019 Tentang Manajemen Penyidikan Tindak Pidana.

Sanksi pidana yang dijatuhkan terhadap pelaku kejahatan diharapkan memberi pencegahan kepada masyarakat juga pelaku sendiri supaya tidak lagi berbuat kejahatan. Akan tetapi terkadang tujuan ini terjadi kegagalan sehingga ada kalanya pelaku malahan menjadi residivis serta masyarakat sendiri bisa meniru untuk berbuat kejahatan. Ini juga dikarenakan penerapan sanksi pidana tidak melihat akar persoalan kejahatan yang sebenarnya. Oleh sebab itu diperlukan pendekatan sosial selain penerapan sanksi pidana

Dalam pelaksanaan penahanan ada kemungkinan terjadinya penyalahgunaan wewenang, baik karena kurangnya keterampilan serta pemahaman aparat ataupun karena kelalaian. Selain karena kurangnya ketrampilan dan pemahaman akan hak asasi manusia yang menjadi inti dari prinsip proses hukum yang adil, terjadinya berbagai penyimpangan dalam praktik pelaksanaan penahanan juga dikarenakan undang-undang tidak tuntas mengaturnya secara mendetail, sehingga dalam banyak hal diserahkan kepada praktik serta kebiasaan yang seharusnya tidak boleh menyimpang dari rumusan Undang-Undang serta prinsip perlindungan hak asasi manusia yang dijunjung tinggi oleh KUHAP

Polisi merupakan bagian dari pemerintah/eksekutif berwenang untuk menangkap dan menahan seorang tersangka. Alasan tidak menghambat tugas penyidik dalam mengumpulkan bukti-bukti yang akan dipakai untuk mendakwanya. Pada keadaan seperti ini, tersangka tidak memiliki daya untuk membela ketika polisi menyiksanya baik secara fisik maupun mental. Akhirnya persoalan pelaksanaan penahanan dalam penelitian ini dititik beratkan pada tahap pemeriksaan pendahuluan, mengingat meskipun tahap ini bukan merupakan tahap yang dominan dalam sistem peradilan pidana, tetapi pelaksanaan penahanan merupakan bagian tak terpisahkan dalam usaha mewujudkan tujuan pemidanaan, bahkan polisi merupakan unsur yang kritis di dalam keadilan serta sangat besar pengaruhnya.

\section{METODE}

Penulisan ini memakai pendekatan Yuridis Empirik (Sosio Yuridis) ialah penelitian hukum mengenai pemberlakuan atau implementasi ketentuan hukum normatif secara in action pada setiap peristiwa hukum tertentu yang terjadi dalam masyarakat, metode pendekatan yuridis empirik digunakan untuk mengkaji atau menganalisis data primer yang berupa data - data di lapangan tempat penelitian, hasil wawancara langsung yang diajukan ke responden kemudian dihubungkan dengan data - data sekunder berupa bahan bahan hukum, untuk menganalisis tanggung jawab Penyidik Kepolisian Terhadap Tersangka Yang Melarikan Diri Dan Masih Dalam Tahap Penahanan Penyidik Pada Kepolisian Daerah Sulawesi Barat.

Data yang diperoleh ditempuh dengan menggunakan teknik pengumpulan Data dalam Bentuk penelitian kepustakaan yaitu teknik pengumpulan data dengan cara mempelajari berbagai literatur baik buku artikel maupun materi kuliah yang diperoleh.Bentuk wawancara yaitu teknik pengumpulan data dengan cara, penulis melakukan wawancara langsung dengan Informan dari Ditreskrimum Polda Sulawesi Barat, Dittahti Polda Sulawesi Barat, dan Bid Propam Polda Sulawesi Barat.

Data yang diperoleh baik primer maupun sekunder dianalisis secara kualitatif, kemudian disajikan secara deskriptif yaitu menjelaskan, menguraikan, dan menggambarkan sesuai dengan permasalahan yang erat kaitannya dengan penelitian ini

\section{HASIL DAN PEMBAHASAN}

\subsection{Tanggung Jawab Penyidik Terhadap Tersangka Yang Melarikan Diri Dan Masih Dalam Tahap Penahanan Penyidik Pada Kepolisian Daerah Sulawesi Barat}

Hukum acara pidana (KUHAP) penahanan merupakan salah satu upaya paksa di antara lima upaya paksa, yakni penangkapan, penahanan, penyitaan, penggeledahan, dan pemeriksaan surat. Dikatakan sebagai upaya paksa karena biasanya dilaksanakan dengan cara menggunakan kekerasan atau kekuasaan paksa. Cara -cara menggunakan paksaan dan atau kekerasan dalam proses pidana dapat dibagi menjadi tiga kelompok, yaitu : (1) memasuki ruang; (2) langkah-langkah yang dapat diterapkan pada benda; (3) langkah-langkah yang dapat diterapkan pada manusia, dalam bentuk pembatasan kemerdekaan, yaitu penangkapan dan penahanan.

Di samping sebagai salah satu instrument penegak hukum pidana, perlu diingat bahwa pada hakekatnya penahanan adalah perampasan atau pencabutan kemerdekaan orang lain yang menimbulkan perasaan tidak enak (sengsara) dan akan membawa konsekuensi hukum maupun sosiologi yang luas baik bagi orang yang ditahan maupun keluarganya karena sifatnya yang eksesif yakni orang yang belum bersalah secara hukum, tapi dalam masyarakat sudah dianggap bersalah.

Kitab Undang - Undang Hukum Pidana suatu tindakan penahanan dapat pula menjadi suatu tindakan pidana kejahatan yang diancam dengan pidana maksimum delapan tahun penjara sebagaimana diancam dalam beberapa Pasal KUHP yang mengancam pidana bagi tindakan penahanan orang secara tidak sah atau bertentangan dengan ketentuan undang-undang. Oleh karena itu dengan keluarnya KUHAP No. 8 Tahun 1981 aparat penegak hukum dalam proses peradilan pidana harus lebih berhati-hati dan selektif dalam melaksanakan penahanan. Berbagai persyaratan maupun prosedur yang telah ditentukan secara normatif harus dipenuhi dan dipatuhi. KUHAP adalah untuk mengatur perilaku dan tindakan para penegak hukum. Ibarat suatu permainan, KUHAP diciptakan agar para penegak hukum yang bermain itu tidak bermain kayu yang mengakibatkan timbulnya pelanggaran hak asasi manusia Pelaksanaan penahanan ini, KUHAP benar-benar diuji apakah bisa membina sikap aparat penegak hukum sesuai dengan fungsi dan kewenangan masing-masing kearah tegaknya hukum, keadilan dan perlindungan harkat martabat manusia. Dikatakan demikian karena dalam pelaksanaan penahanan terbuka kemungkinan yang besar bagi terjadinya penyalahgunaan wewenang karena tersangka ditempatkan di bawah kekuasaan aparat yang melakukan penahanan terisolir dari masyarakat umum. Tidak saja hak asasi kemerdekaan manusia yang dapat dilanggar tetapi mungkin pula terjadinya penyiksaan fisik, teror mental, 
bahkan kematian tersangka, dimana hal itu tidak terjadi bila tersangka tidak dikenakan penahanan.

Perlu pula dikemukakan, bahwa membicarakan penahanan erat kaitannya dengan penangkapan, sebab pada umumnya penahanan dilakukan setelah terlebih dahulu dilakukan penangkapan dan sebaliknya tindakan penahanan selalu diikuti dengan penahanan. Dalam kehidupan sehari-hari orang (awam) sering menganggap bahwa penahanan sama dengan penangkapan karena pada dasarnya penangkapan dan penahanan merupakan perampasan hak asasi seseorang untuk waktu tertentu. Pada masa berlakunya HIR dikenal istilah penangkapan sementara yang jangka waktunya 20 hari (Pasal 27 HIR). Bagi polisi penangkapan dan penahanan adalah bagian dari wewenang yang sangat penting .

Pandangan yang mempersamakan penangkapan dan penahanan sebenarnya kurang tepat, kedua istilah tersebut mempunyai perbedaan pengertian maupun konsekuensi yang diakibatkannya, walaupun sebenarnya pemahaman demikian sebenarnya bukan tanpa dasar. Keduanya merupakan pranata hukum yang berbeda baik dalam teknis pelaksanaan serta syarat-syaratnya maupun konsekuensi hukumnya.

Selanjutnya dalam memahami konsep penahanan dalam peradilan pidana perlu dipahami beberapa model yang bekerja dalam proses peradilan pidana. bekerjanya proses peradilan pidana dapat dijelaskan melalui dua buah model, yaitu "crime control model" dan "due process model" Tetapi kedua model itu hanyalah sekedar "normative models" yang membantu kita dalam menganalisis bekerjanya proses peradilan pidana sehari-hari

Sistem yang bekerja pada "crime control model" didasarkan pada prinsip bahwa penekanan jumlah kejahatan merupakan fungsi utama peradilan pidana. Kegagalan fungsi ini merupakan gangguan terhadap ketertiban umum dan kebebasan.Untuk mencapai tujuan demikian ini, proses criminal harus dilakukan secara efisien, segala rintangan prosedur yang dapat menjadi hambatan bagi pelaksanaan proses criminal harus disingkirkan.

Proses peradilan pidana diibaratkan seperti ban berjalan, dimana masing-masing petugas penegak hukum berdiri pada posisinya sendiri. Dalam hal ini proses peradilan pidana merupakan suatu proses penyaringan dan dalam tiap-tiap tahap dilakukan tindakan-tindakan yang bersifat rutinitas. Keberhasilan pertama-tama diukur sesuai dengan tindakan keberhasilan penyelesaian kasus demi kasus untuk mencapai tujuan yaitu mengurangi atau menanggulangi kejahatan.

Menurut Kompol Yuslim Yunus apabila ada tersangka yang melarikan diri dan masih dalam tahap penahanan penyidik maka tanggung jawab dari Penyidik yaitu :

Melaporkan ke pimpinan dan membuat laporan terkait tahanan yang melarikan diri tersebut. Dalam hal ini apabila ada tahanan yang melarikan diri maka seorang penyidik harus sesegera mungkin melaporkan ke pimpinan dan membuat laporan terkait kronologis kejadian tahanan yang melarikan diri tersebut.

Melakukan pencarian terhadap tahanan yang melarikan diri tersebut. Dalam hal ini apabila ada tahanan yang melarikan diri maka penyidik harus sesegera mungkin melakukan pencarian terhadap tahanan tersebut, karena akan dilimpahkan ke Jaksa Penuntut Umum untuk dilakukan penuntutan.

Membuat Daftar Pencarian Orang (DPO) terhadap tahanan yang melarikan diri kemudian menyebarkan ke wilayah - wilayah. Dalam hal ini apabila ada tahanan yang melarikan diri maka penyidik harus membuatkan Daftar Pencarian Orang (DPO) terhadap tahanan yang melarikan diri tersebut yang memuat foto dan identitas lengkap dari tersangka tersebut dan menyebarkan ke wilayah - wilayah.

3.2 Sanksi yang dijatuhkan kepada penyidik terhadap tersangka yang melarikan diri yang masih dalam tahap penahanan penyidik pada Kepolisian Daerah Sulawesi Barat

Sebagai Anggota Polri dalam menjalankan tugasnya harus menaati peraturan yang mengikat anggota Polri tersebut. Menurut personil Bid Propam Polda Sulbar Brigpol Suriadi jika tahanan melarikan diri maka terhadap petugas yang melaksanakan tugas pada saat itu dipersangkakan melanggar Pasal 4 huruf d Peraturan Pemerintah Nomor 2 tahun 2003 tentang peraturan disiplin anggota Kepolisian Negara Republik Indonesia, adapun bunyi pasal 4 huruf d yaitu "melaksanakan tugas sebaik - baiknya dengan penuh kesadaran dan rasa tanggung jawab", dan sanksi yang dijatuhkan bagi anggota Kepolisian tersebut berupa hukuman disiplin yang termuat dalam Pasal 9 Peraturan Pemerintah nomor 2 tahun 2003 tentang peraturan disiplin anggota Kepolisian Negara Republik Indonesia yaitu sebagai berikut :

1. Teguran tertulis yaitu teguran yang diberikan secara tertulis kepada anggota Polri karena tidak mematuhi aturan yang berlaku dan mengikat bagi anggota Polri itu sendiri.

2. Penundaan mengikuti pendidikan paling lama 1 (satu) tahun yaitu sanksi yang diberikan kepada anggota polri karena tidak mematuhi aturan yang mengikat anggota polri dengan tidak diperbolehkan mengikuti segala pendidikan yang ada dalam lingkungan Polri.

3. Penundaan kenaikan gaji berkala yaitu sanksi yang diberikan kepada anggota polri karena tidak mematuhi aturan yang mengikat anggota polri dengan tidak diberikannya hak berupa kenaikan gaji yang didapatkan setiap 2 tahun sekali.

4. Penundaan kenaikan pangkat untuk paling lama 1 (satu) tahun yaitu sanksi yang diberikan kepada anggota polri karena tidak mematuhi aturan yang mengikat anggota polri dengan tidak diberikan haknya untuk kenaikan pangkat setingkat lebih tinggi.

5. Mutasi yang bersifat demosi yaitu sanksi yang diberikan kepada anggota polri karena tidak mematuhi aturan yang mengikat anggota polri dengan diturunkan eselon jabatannya dari jabatan semula.

6. Pembebasan dari jabatan yaitu sanksi yang diberikan kepada anggota polri karena tidak mematuhi aturan yang mengikat anggota polri dengan dibebaskan dari kewenangan dan tanggungjawabnya dari jabatannya.

7. Penempatan dalam tempat khusus paling lama 21 (dua puluh satu) hari yaitu sanksi yang diberikan kepada anggota polri karena tidak mematuhi aturan yang 
mengikat anggota polri dengan ditempatkannya pada tempat yang berada dalam pengawasan ankum (atasan yang berhak menghukum).

Adapun upaya - upaya yang dilakukan POLRI khususnya Kepolisian Daerah Sulawesi Barat dalam melakukan tanggung jawabnya sebagai penegak hukum terhadap tahanan meliputi :

1. Upaya Preventif ialah memberikan pemahaman kepada masyarakat tentang bagaimana proses penahanan yang baik sesuai dengan prosedur, serta memberikan pengetahuan bahwa penahanan yang dilakukan tidak semerta-merta karena menjustifikasi seseorang telah bersalah dan menjelaskan hak-hak nya selama proses penahanan berlangsung.

2. Upaya Represif ialah melakukan pengawasan ketat terhadap aparat kepolisian yang mempunyai tanggung jawab dalam hal proses penahanan, memberikan sanksi yang tegas ketika tanggung jawabnya sebagai penegak hukum terhadap tahanan tidak berjalan sebagaimana mestinya baik berupa sanksi teguran, penurunan pangkat sampai kepada pemecatan tujuannya agar pelaksanaan proses penahanan dan tanggung jawab kepolisian terhadap tahanan dapat berjalan sesuai dengan peraturan perundang-undangan yang berlaku

\section{KESIMPULAN DAN SARAN}

Hasil penelitian dan pembahasan dapat disimpulkan bahwa tanggung jawab penyidik terhadap tersangka yang melarikan diri dan masih dalam tahap penahanan penyidik pada Kepolisian Daerah Sulawesi Barat sudah berjalan secara optimal, karena penyidik telah melaksanakan tugas sesuai Standar Operasional Prosedur (SOP) yang ada (membuat Daftar Pencarian Orang / DPO dan melakukan pencarian terhadap tersangka yang melarikan diri tersebut hingga tersangka berhasil ditemukan). Penyidik melanjutkan tugas penyidikan, selanjutnya melimpahkan ke Jaksa Penuntut Umum (JPU) jika berkas sudah dinyatakan lengkap (P-21). Melaporkan dalam Resume (Kesimpulan Penyidikan) tentang perbuatan tersangka yang melarikan diri saat ditahan pada proses dipenyidikan.

\section{DAFTAR PUSTAKA}

Abdurrachman. A,,1989 Perkembangan Pemikiran Tentang Pembinaan Hukum Nasional, Jakarta; Akademika Presidon,

Bambang Waluyo, 1992 Implementasi Kekuasaan Kehakiman Republik Indonesia, Sinar Grafika Edisi 1 Cet. 1. Jakarta

Bernard L, Tanya Hukum Politik dan KKN Surabaya; Srikandi 2006.

Bonger W.A. 1962 Pengantar Tentang Kriminologiterjemahan R.A Koenoen, Penerbit PT. Pembangunan Jakarta

Harun M Husein, 1990,Kejahatan dan Penegakan Hukum di Indonesia, Jakarta: Rineka Cipta.

Luhut M.P. Pangaribuan, 2002, Advokat dan Contempt of Court; Suatu Proses di Dewan Kehormatan Profesi, Djambatan, Jakarta, Edisi Revisi

Mulyana, Deddy. 2002. Metode Penelitian Kualitatif. Bandung: PT. Remaja Rosdakarya

Nico Ngani, I Nyoman Budi Jaya; Hasan Madani, 1984,Mengenal Hukum Acara Pidana, Bagian Umum Dan Penyidikan. (Yogyakarta: Liberty)
Nurfaika Ishak. 2019. Implementation and Supervision of Official Discretion in Local Government of Republic of Indonesia. Jurnal Al Daulah: Jurnal Hukum Pidana dan Ketatanegaraan. Vol.8 No.2 Desember 2019.

Purwanto, Iwan. 2006. Manajemen Strategi.Bandung : CV Yrama Widya

Ridwan HR, 2008. Hukum Administrasi Negara Jakarta, PT Grafindo Persada

Ruslan Renggong, Hukum Acara Pidana : Memahami Perlindungan HAM Dalam Proses Penahanan Di Indonesia, Jakarta : Prenada Media Group 2014

Santoso, Topo, dan Eva Achjani Zulfa. 2001. Kriminologi.Jakarta : PT Rajagrafindo Persada

IT Umbara, R Renggong, AH Hamid.2020.Peran Pembimbing Kemasyarakatan Sebagai Penegak Hukum Dalam Pencegahan Pengulangan Tindak Pidana Pada Balai Pemasyarakatan Kelas I Makassar.Indonesian Journal of Legality of Law.2 : 126-130 